\title{
Correlation Analysis of Working Capital Management and Corporate Performance in Manufacturing Industry: A Perspective of Supply Chain
}

\author{
Zhou Hong ${ }^{1,}{ }^{*}$, Wang Jingyi ${ }^{2}$ \\ ${ }^{1}$ Zhejiang University City College, Hangzhou, China \\ 2 Naveen Jindal School of Management, UTD, USA \\ *zhouh08@126.com
}

\begin{abstract}
Working capital management is the foundation of enterprise fund management. In this paper, from the perspective of supply chain, the manufacturing industry is divided into three stages, namely, primary raw materials, equipment and final consumer goods suppliers. The author collected the related financial data from 2013 to 2015, including 2294 samples, and constructed 8 multiple regression models, to study the difference of the relationship between working capital management efficiency and corporate performance in different stages. The results show that the overall efficiency of the company's working capital operation is higher, the better the performance of the company is, whether it is the whole or grouping sample. The results further show that the relationship between working capital and corporate performance has obvious difference at different stages of supply chain. In the upstream industry, accounts payable is more important; for downstream industry, accounts receivable is more important. This conclusion is expected to provide a useful reference for the company's working capital management.
\end{abstract}

Keywords: working capital management. cash conversion cycle. supply chain. company performance. manufacturing industry.

\section{Introduction}

Working capital is one of the most liquid, most rapidly changing and strongest turnover funds of the enterprise. Correct working capital management (WCM) is a necessary requirement for the survival of enterprises. WCM is the foundation of enterprise fund management (Horne \& Wachowicz, 2009). Many companies invest a large amount of cash in working capital, but also treat a large number of short term accounts payable as a source of financing (Sun, et al., 2015). According to statistics, working capital takes on average $60 \%$ of the total capital in China's manufacturing industry, and some enterprises can account for more than $80 \%$; many of the company's financial managers will put most of their energy into the daily WCM. For enterprise managers, efficient management of working capital is an investment behavior of creating value, which is an indispensable part of the strategy of creating shareholder value.

Since 1980s, people have paid more attention to the research of WCM, to exploration of WCM efficiency index, and to studying the relationship between WCM policy and corporate profitability. In theory, the improvement of WCM efficiency should be in consistent with the improvement of overall profitability of the enterprise. But in practice, it is necessary to do an in-depth discussion and argument that if a shorter cash cycle can really be conducive to enterprise profitability, if there are significant differences between different industries for the impact of turnover of capital on earnings, and how different components of working capital impact on management efficiency.

\section{Literature Review}

The theoretical research on working capital has experienced a process from normative research to empirical research. Early WCM efficiency indicators commonly used are inventory turnover period and accounts receivable turnover period. These indicators only take the management of current assets into consideration, ignoring the impact current liabilities can make to other assets. Gitman (1974), 
Hager (1976), Richard and Laughlin (1980) successively put forward the concept of cash conversion cycle (CCC). They define CCC as a net time interval for the purchase of cash payments to the end product sales.

By considering quantity and time of cash flow in each phase, Gentry, Vaidyanathan and Lee (1990) established an index of weighted cash conversion cycle (WCCC). However, calculating WCCC is difficult because it requires enterprise's internal data. Therefore, the use of WCCC is limited.

Recently, the research on the relationship between WCM efficiency and corporate profitability has become more and more important. Jose Manual et al. (1996) first discovered through empirical studies, the shorter the cash flow period, the higher the income. Deloof(2003) by studying the sample of 1009 non-financial companies in Belgium in 1992-1996, found that the accounts receivable cycle and inventory cycle is negatively related to corporate performance, and the payable period is positively related to corporate performance. Similar studies, such as Raheman et al. (2010) by researching Pakistan 204 manufacturing listed companies' panel data from 1998 to 2007, found the CCC, net trade cycle and inventory turnover in days on corporate performance negatively correlated. The research of Godfred (2016) also got the similar conclusion.

Many scholars study the efficiency of WCM in different industries, and explore the difference between industries. Through the comparative analysis of 12 industries in China listing Corporation, Wang and $\mathrm{Wu}$ (2007) found that WCM has significant difference. Viskari et al. (2012) think that the value chain partners can work together to increase the profitability of the value chain. Lind et al. (2012) using the descriptive financial value chain analysis method, dividing the automobile industry into six stages, namely the raw material suppliers, refined raw material suppliers, component suppliers, system suppliers, car manufacturers and car dealers, found that the change of working capital turnover is mainly decided by the change of time of inventories turnover.

However, for studying the impact of efficiency of WCM on business performance, the existing literature is often viewed in isolation, or simply descriptive analysis. It is necessary to carry out a comparative study on the correlation of the industry through statistical testing methods. Aiming at the deficiency of existing research, this paper attempts to analyze from the perspective of supply chain, using statistical regression method, dividing manufacturing sectors into three stages, namely primary raw materials suppliers (Stage 1), equipment suppliers (Stage 2) and final consumer goods suppliers (Stage 3), and to explore the characteristics and rules of WCM efficiency and performance of different stages of manufacturing enterprises.

\section{Research Methodology}

\section{1 variables selection.}

The dependent variables in this paper represent the level of corporate performance. Return on Assets (ROA) or return on equity (ROE) is a commonly used performance indicator. Because this paper studies the relationship between working capital operation efficiency and corporate performance, it is more appropriate to choose ROA. The independent variables and control variables used in this study are shown in Table 1.

Table 1 Various variables and instructions

\begin{tabular}{|l|l|l|}
\hline Variable type & \multicolumn{1}{|c|}{ Variables } & \multicolumn{1}{c|}{ Variable description } \\
\hline $\begin{array}{l}\text { Dependent } \\
\text { Variables }\end{array}$ & Return on Assets & ROA $=$ Net Income / Total Assets \\
\hline \multirow{3}{*}{$\begin{array}{l}\text { Independent } \\
\text { variables }\end{array}$} & Receivable Turnover in Days & $\mathrm{RTD}=365^{*}$ Accounts Receivable / Net Sales \\
\cline { 2 - 3 } & Inventory Turnover in Days & $\mathrm{ITD}=365^{*}$ Inventory /Cost of Goods Sold \\
\cline { 2 - 3 } & Payable Turnover in Days & $\mathrm{PTD}=365^{*}$ Accounts Payable / Credit Purchases \\
\cline { 2 - 3 } & Cash Conversion Cycle & $\mathrm{CCC}=$ RTD-ITD-PTD \\
\hline $\begin{array}{l}\text { Control } \\
\text { Variables }\end{array}$ & Firm size & Ln Total Assets \\
\cline { 2 - 3 } & Debt to Total Assets Ratio & DAR $=$ Total Debt / Total Assets \\
\hline
\end{tabular}




\subsection{Sample and data}

Different from previous studies, this paper divides manufacturing into three stages, namely, the front end - primary raw material suppliers, the back end - the Final consumer goods suppliers, and the tributary - equipment suppliers.

The primary raw materials suppliers (Stage 1) consist mainly of petroleum processing, coking and nuclear fuel processing, chemical raw materials and products, chemical fiber, non-metallic mineral products, ferrous metal smelting and rolling processing, non-ferrous metal smelting and rolling processing manufacturing. Equipment suppliers (Stage 2) mainly include special equipment, railways, ships, aerospace and other transportation equipment manufacturing industry as well as electrical machinery and equipment manufacturer. The final consumer goods suppliers (Stage 3) contain of food, clothing, furniture, textile art, stationery and sports goods, and automobile manufacturer.

This paper selects the manufacturing sectors of Shanghai and Shenzhen A-share listed companies as samples, collected relevant financial data from 2013 to2015, excluding *ST and ST companies as well as companies with missing data. As a result, this research select of 881 sample for Stage 1, 971 sample for Stage 2, and 442 sample of Stage 3. All related data in this paper are obtained from the database of CSMAR, and data are verified through professional financial websites and listed companies' annual reports.

\subsection{Model Design}

In this paper, we use the previous research model, and establish the following multiple regression models. In addition to researching the entire sample of the manufacturing industry, we will examine the differences between the efficiency of WCM and the performance of different stages in the primary raw materials manufacturing, equipment manufacturing and final product manufacturing industry.

$$
\begin{aligned}
& Y_{\mathrm{i}}=\beta_{0}+\beta_{1} C C C_{\mathrm{i}}+\beta_{2} D A R_{\mathrm{i}}+\beta_{\mathrm{a}} S I Z E_{\mathrm{i}}+\varepsilon_{\mathrm{i}} \\
& Y_{\mathrm{i}}=\beta_{0}+\beta_{1} R T D_{\mathrm{i}}+\beta_{2} I T D_{\mathrm{i}}+\beta_{\mathrm{a}} P T D_{\mathrm{i}}+\beta_{4} D A R_{\mathrm{i}}+\beta_{5} S I Z E_{\mathrm{i}}+\varepsilon_{\mathrm{i}}
\end{aligned}
$$

The dependent variable $\mathrm{Y}$ is ROA.

\section{Empirical Analyses}

According to all samples and three sub sectors, this research establishes 8 multiple regression models, in order to test the efficiency of working capital efficiency indicators CCC, ITD, RTD and PTD on the impact of corporate performance.

As seen from the Table 2- Table 9, the VIF values of all the variables of the 8 models are much lesser than 10 , which indicates that there is no multiple co linearity between variables.

\subsection{Test for all sample}

As can be seen from Table 2 and Table 3, for the whole sample, the cash cycle was significantly negatively correlated with ROA. Inventory cycle, accounts receivable cycle and ROA also showed a significant negative correlation. However, the accounts payable period was significantly positively correlated with ROA. As for the control variables, the asset liability ratio and ROA is significantly negative correlation, the relationship between enterprise scale and performance is not obvious.

Table 2 Regression of cash cycle for all samples

\begin{tabular}{|l|c|c|c|c|c|}
\hline & Un. C. & S. C. & $\mathrm{t}$ & Sig. & VIF \\
\hline Const. & .109 & & 4.249 & .000 & \\
\hline CCC & .000 & -.147 & -7.084 & .000 & 1.075 \\
\hline DAR & -.062 & -.274 & -12.868 & .000 & 1.133 \\
\hline SIZE & -.002 & -.031 & -1.442 & .149 & 1.147 \\
\hline Adj-R ${ }^{2}$ & 0.291 & D-W & 1.874 & F & 70.619 \\
\hline
\end{tabular}

Table 3 Regression of segment index for all samples

\begin{tabular}{|c|c|c|c|c|c|}
\hline & Un. C. & S. C. & $\mathrm{t}$ & Sig. & VIF \\
\hline C & .098 & & 3.784 & .000 & \\
\hline ITD & .000 & -.119 & -5.350 & .000 & 1.250 \\
\hline RTD & .000 & -.087 & -3.631 & .000 & 1.457 \\
\hline PTD & .000 & .170 & 7.266 & .000 & 1.381 \\
\hline DAR & -.064 & -.283 & -13.264 & .000 & 1.144 \\
\hline SIZE & -.001 & -.027 & -1.239 & .216 & 1.172 \\
\hline Adj-R $^{2}$ & 0.305 & D-W & 1.983 & F & 46.794 \\
\hline
\end{tabular}




\subsection{Test for primary raw materials suppliers (Stage 1)}

From Table 4 and Table 5 can be seen, for primary raw materials suppliers, CCC and ROA are significant negative correlated. ITD is significant negative correlated with ROA. PTD is significantly positive correlated with ROA. However, RTD is not significant correlated with ROA. Compared with the standardized coefficient, the coefficient of PDT for stage 1 is obviously higher, which shows that it has the greatest impact on business performance.

Table 4 Regression of cash cycle for Stage 1

\begin{tabular}{|l|c|c|c|c|c|}
\hline & Un. C. & S. C. & $\mathrm{t}$ & Sig. & VIF \\
\hline Const. & .159 & & 2.845 & .005 & \\
\hline CCC & .000 & -.140 & -4.085 & .000 & 1.091 \\
\hline DAR & -.090 & -.201 & -5.312 & .000 & 1.324 \\
\hline SIZE & -.004 & -.050 & -1.359 & .175 & 1.267 \\
\hline Adj-R $^{2}$ & 0.231 & D-W & 2.075 & F & 16.439 \\
\hline
\end{tabular}

\subsection{Test for equipment suppliers (Stage 2)}

From the Table 6 and Table 7 can be found, for equipment suppliers, CCC is significantly negative correlated with ROA. ITD and RTD are also significantly negatively correlated, but the correlation between PTD and ROA is not significant. Compared with the standard coefficient, the coefficient of RTD is slightly higher than ITD, which indicates that the impact of RTD on business performance is greater than ITD.

Table 6 Regression of cash cycle for Stage 2

\begin{tabular}{|c|c|c|c|c|c|}
\hline & Un. C. & S. C. & $\mathrm{t}$ & Sig. & VIF \\
\hline Const. & -.087 & & -2.995 & .003 & \\
\hline CCC & .000 & -.269 & -9.235 & .000 & 1.035 \\
\hline DAR & -.117 & -.485 & -13.962 & .000 & 1.469 \\
\hline SIZE & .009 & .212 & 6.137 & .000 & 1.448 \\
\hline Adj-R $^{2}$ & 0.205 & D-W & 1.977 & F & 84.087 \\
\hline
\end{tabular}

Table 5 Regression of segment index for Stage 1
\begin{tabular}{|c|c|c|c|c|c|}
\hline & Un. C. & S. C. & t & Sig. & VIF \\
\hline Const. & .070 & & 1.246 & .213 & \\
\hline ITD & .000 & -.142 & -4.138 & .000 & 1.197 \\
\hline RTD & .000 & -.032 & -.811 & .418 & 1.583 \\
\hline PTD & .001 & .365 & 10.094 & .000 & 1.341 \\
\hline DAR & -.110 & -.246 & -6.644 & .000 & 1.400 \\
\hline SIZE & .000 & -.006 & -.174 & .862 & 1.374 \\
\hline Adj-R ${ }^{2}$ & 0.381 & D-W & 2.113 & F & 29.744 \\
\hline
\end{tabular}




\section{Conclusion}

Full sample test results show that the shorter the cash flow period, the better the performance. From segment index of working capital, the shorter inventory turnover period and faster accounts receivable collection, the better the performance of enterprise. The longer accounts payable payment period, the better the performance of enterprise.

For the grouping test, whether it is for stage1, stage 2 or stage $3, \mathrm{CCC}$ is significant negative correlated with corporate performance, indicating that the higher of overall efficiency of working capital operation, the better the corporate performance.

The influence level of working capital is obvious different for different stages on the performance of enterprises. The WCM of enterprises of stagel depends on accounts payable period, and it has no significant relationship with the accounts receivable cycle. In stage 2 , accounts receivable cycle and the inventory cycle are very important, but there is no obvious relationship between payable receivable cycle and corporate performance. In stage 3, all three segment index are very important. The influence level of working capital turnover period from largest to smallest would be receivables cycle, accounts payable period, and inventory cycle.

From the perspective of supply chain, the above conclusions can be understood as, for companies closer to the upstream of the supply chain, account payable is more important. On the contrary, for companies closer to the downstream of the supply chain, accounts receivable is more important.

\section{References}

[1] J.C.V. Horne, J. M. Wachowicz: Fundamentals of Financial Management, 13e, Tsinghua University press, (2009)

[2] Y. Sun, Z. Wang et al.: Survey of working capital management of listing Corporation in China: 2014. Accounting Research, 12(2015), p.67

[3] V. D. Richards, E. J. Laughlin: A cash conversion cycle approach to liquidity analysis. Financial Management, Spring (1980). P.32

[4] J. A. Gentry, R. Vaidyanathan and H. Lee: A Weighted Cash Conversion Cycle, Financial Management (Spring). (1990), p.29

[5] L. J. Manuel, L. Carol and L. S. Jerry: Corporate Returns and Cash Conversion Cycles .Journal of Economics and Finance, Spring, (1996), p.33

[6] Deloof: Does Working Capital Management Affects profitability of Belgian Firms? Journal of Business Finance \& Accounting. 30(3) \& (4), (2003), p.573

[7] A. A. Godfred: Net working capital, cash flow and performance of UK SMEs, Review of Accounting and Finance, Vol. 15(1), (2016), p.1191

[8] L. Lind, M. Pirttil, S. Viskari, F. Schupp and T. Karri: Working capital management in the automotive industry: Financial value chain analysis. Journal of Purchasing \& Supply Management, Vol.18(2), (2012), p.92

[9] S. Viskari, L. Lind, T. Karri and F. Schupp: Using working capital management to improve profitability in the value chain of automotive industry, International Journal of Services and Operations Management, Vol.13(1), (2012),p.42

[10]Z. Wang, N. Wu: Industry differences and its influencing factors in working capital management. Finance and Accounting Monthly, 9 (2007), p.3 